\title{
Acta Veterinaria Brasilica
}

Journal homepage: https://periodicos.ufersa.edu.br/index.php/acta/index

Original Article

\section{Oral microbiota in healthy Bothrops atrox (Serpentes: Viperidae) and in snakes with stomatitis}

\author{
Heloisa Castro Pereira1, Dayane Olímpia Gomes¹, Líria Queiroz Luz Hirano2*, André Luiz Quagliatto Santos², \\ Anna Monteiro Correia Lima ${ }^{1}$ \\ ${ }^{1}$ Laboratório de doenças Infectocontagiosas, Universidade Federal de Uberlândia, Uberlândia, MG, Brasil. \\ ${ }^{2}$ Laboratório de Ensino e Pesquisa em Animais Silvestres, Faculdade de Medicina Veterinária, Universidade Federal de Uberlândia, \\ Uberlândia, MG, Brasil.
}

\section{A R T I C L E I N F O}

\section{Article history}

Received 06 June 2017

Received in revised form 07 July 2017

Accepted 19 July 2017

\section{Keywords:}

Bacteriological

Ophidia

Reptilia

\section{INTRODUCTION}

In Brazil, Bothrops and Crotalus are the genera of snakes most widely related with snake bites (BERNARDE, 2014). Jararaca from north of Brazil belongs to the family Viperidae, sub-family Crotalinae, genus Bothrops and species Bothrops atrox Linnaeus, 1758 (COSTA; BÉRNILS, 2015). Antivenom and medicines are researched and produced using a few fractions of the venom of snakes belonging to the genus Bothrops. The main toxic fractions in Bothrops venom are metalloproteinases and bothropsin. Thrombi may be formed, leading to renal ischemia due to decreased blood perfusion (CASTRO, 2006).

At most Bothrops breeding facilities, venom is extracted monthly by hand to prevent the formation of oral lesions, which could cause stomatitis. Giannotti et al. (2013), who studied morphological changes in the venom glands of snakes with low venom production, found lesions indicative of excessive pressure applied on the glands during the extraction procedure.

The usual signs of Bothrops sp. snakebite are tissue loss such as edema, abscess and necrosis caused by the action of proteolytic enzymes. In addition, formation of abscesses at the site of the bite is a commonly complication due to the large number of bacteria from the reptile's mouth (JORGE et al., 1994).

According to Jorge et al. (1990), the bacterial species found in the oral cavity of snakes in different regions of the world vary considerably. The main microorganisms found in the microbiota of snakes are Gram negative bacilli that can act opportunistically, causing disease in these animals (KOLENISKOVAS; GREGO; ALBUQUERQUE, 2006).

\footnotetext{
*Corresponding author: liriaqueiroz@yahoo.com.br
} 
The purpose of this study was to identify the bacteria in the oral cavity of healthy Bothrops atrox or of snakes with stomatitis bred in captivity, which are used for venom extraction, in order to determine whether the bacteria found in snakes with stomatitis are part of the normal microbiota of this snake species.

\section{MATERIAL AND METHODS}

Thirty healthy snakes of the species Bothrops atrox, 15 males and 15 females, and 12 Bothrops atrox snakes with stomatitis, eight females and four males were used in the present study (Figure 1). The samples were collected at a commercial snake breeding facility for venom extraction, Pentapharm of Brazil, located in Uberlândia, Minas Gerais, registered under no. 11904 at the Brazilian Institute of Environment and Renewable Natural Resources (IBAMA).

To avoid adding a source of stress for the healthy snakes, the samples were collected during the routine procedures of the breeding facility, which follows all the international standards of animal welfare and biosecurity. The study was approved by SISBIO, Brazil's Biodiversity Authorization and Information System, under Permit no. 41060-1, and by the Animal Research Ethics Committee of the Federal University of Uberlândia, Protocol no. 142/13.

Figure 1. Oral cavity of Bothrops atrox with severe stomatitis.

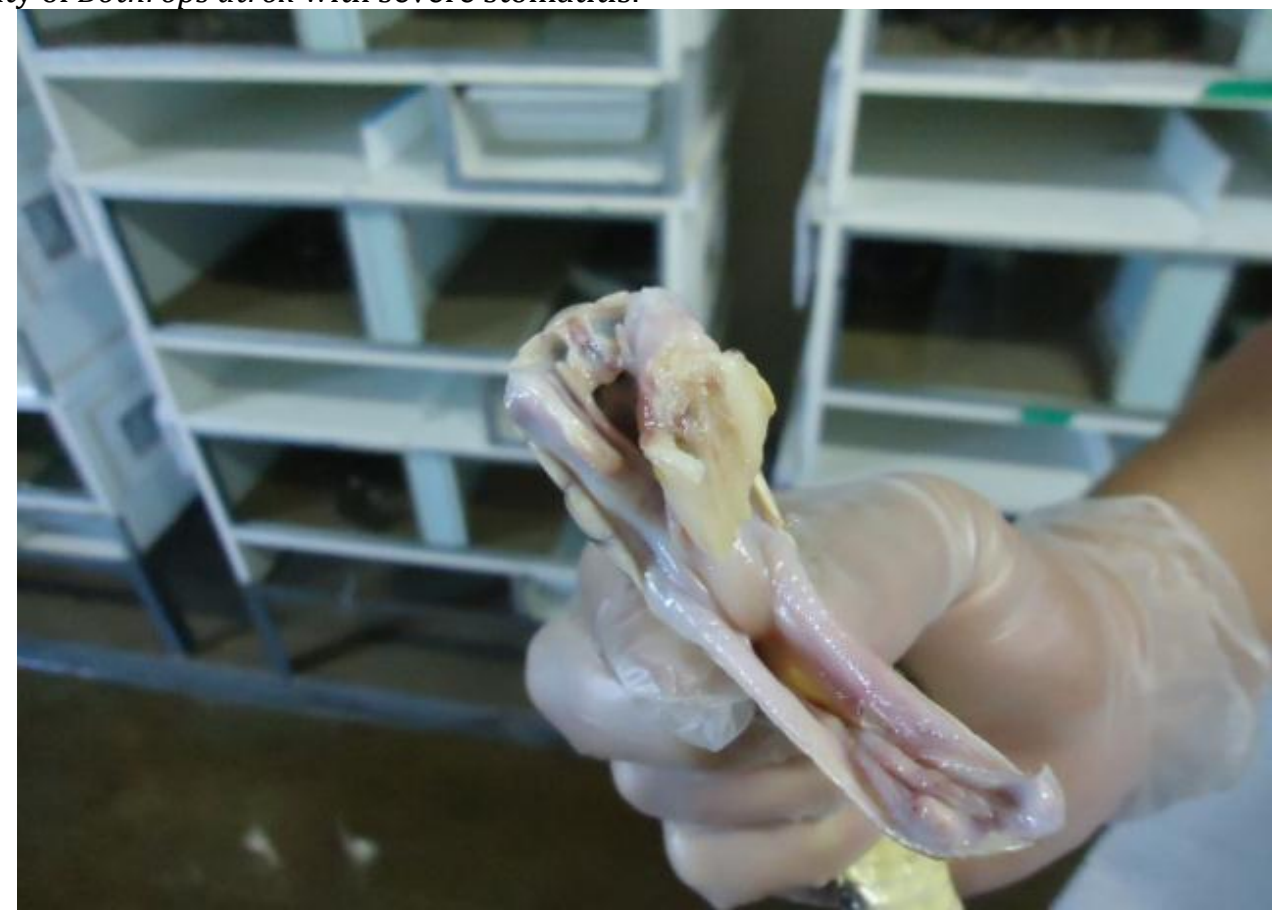

Source: author's collection.

The snakes were physically restrained by placing a hook near the distal third of the head, and then grabbing the region of the animal's temporomandibular joints with the other hand to keep the animal's mouth open (WILKINSON, 2014). The secretion in the oral cavity of each snake was then collected by swabbing around each snake fang sheath with a sterile alginate cotton swab and submitted to microbiological examination.

These samples were stored in tubes containing Stuart transport medium and taken to the Laboratory of Infectious Diseases of the Federal University of Uberlândia. In the laboratory the samples were transferred to tubes containing thioglycollate broth, a highly nutritious medium that favors the growth of various microorganisms, and incubated in a bacteriological incubator at $37^{\circ} \mathrm{C}$ for 24 hours (OPLUSTIL, 2004).
Using a platinum loop, the samples were seeded on Petri dishes containing blood agar and XLD agar (xylose-lysine deoxycholate), using the agar depletion technique, to isolate the bacterial colonies. The seeded dishes were placed in a bacteriological incubator at $3^{\circ}{ }^{\circ} \mathrm{C}$ for 24 hours and incubated again (QUINN et al., 2004).

Gram staining was performed on the blood agar colonies to identify Gram-positive and Gram-negative bacteria. Catalase and Mannitol tests were performed to identify the Gram-positive bacteria (OPLUSTIL, 2004).

The colonies grown on XLD agar were identified using commercial mini kits containing Rugai-lysine medium, to biochemically screen colonies growing on media selective for Gram negative bacteria belonging to the family Enterobacteriaceae. Rugai-lysine medium was used for each different XLD agar colony in order to identify each bacterial genus or species, as 
recommended by the manufacturer (OPLUSTIL, 2004). A statistical analysis was performed using Fisher's exact test, considering $5 \%$ of significance.

\section{RESULTS AND DISCUSSION}

Bacterial growth occurred in the thirty samples from the oral cavity of healthy Bothrops atrox as well as in the twelve samples from Bothrops atrox with stomatitis, some of which showed the presence of more than one microorganism. The bacteria isolated from the thirty healthy snakes were: Proteus spp. (37.5\%), Escherichia coli (25\%), Citrobacter spp. (18.76\%), Serratia spp. (9.37\%) and Enterobacter spp. (9.37\%), while those isolated from the twelve snakes with stomatitis were: Escherichia coli (26.31\%), Citrobacter spp. (21.05\%), Proteus spp. (15.78\%), Salmonella spp. (10.52\%) and Staphylococcus spp. (26.31\%).

Fisher's exact test revealed a significant difference in Staphylococcus spp. between samples from healthy snakes and from snakes with stomatitis, suggesting that this microorganism is related with cases of stomatitis in Bothrops atrox (Table 1).

Table 1. Frequency of bacteria found in the oral cavity of healthy Bothrops atrox or in snakes with stomatitis.

\begin{tabular}{|c|c|c|c|c|c|}
\hline Bacteria & Healthy snakes (30) & Frequency (\%) & Snakes with stomatitis (12) & Frequency (\%) & "P" value \\
\hline Escherichia coli & 8 & 25.00 & 5 & 26.32 & 0.4635 \\
\hline Staphylococcus spp. & - & - & 5 & 26.32 & 0.0009 \\
\hline Citrobacter spp. & 6 & 18.76 & 4 & 21.05 & 0.4331 \\
\hline Proteus spp. & 12 & 37.50 & 3 & 15.78 & 0.4848 \\
\hline Serratia spp. & 3 & 9.37 & - & - & 0.5453 \\
\hline Enterobacter spp. & 3 & 9.37 & - & - & 0.5453 \\
\hline Salmonella spp. & - & - & 2 & 10.53 & 0.0767 \\
\hline TOTAL & 32 & 100 & 19 & 100 & \\
\hline
\end{tabular}

In a microbiological study of the oral cavity of healthy snakes belonging to the families Boidae, Colubridae, Elapidae and Viperidae, Fonseca et al. (2009) identified the following bacteria: Actinomyces sp., Burkholderia sp., Moraxella sp., Proteus sp., Sarcina sp., Bacillus subtilis, Staphylococcus aureus, coagulase-negative Staphylococcus and Yersinia enterocolitica. Among them, the species Proteus spp. and Staphylococcus spp. were found in B. atrox, suggesting that these bacteria are part of the normal microflora of these reptiles. Staphylococcus spp. was isolated only in Bothrops atrox with stomatitis.

Gram negative bacilli, some of which zoonotic, are the mainly microorganisms found in oral and cloacal microbiota of reptiles, as evidenced in cases of complications after snakebite in humans, in which the site appears infected and sometimes necrotic (MADER, 1998). The Salmonella that was isolated from Bothrops atrox with stomatitis is an example of a zoonotic bacterium, and is widely described as part of the normal microbiota of snakes. Of course, Salmonella is not the only zoonotic bacterium present in snakes, and there are reports of other bacteria such as Chlamydophila spp. and Mycobacterium spp. (WILLIAMS, 2008).

The bacteria found in the oral cavity of healthy Bothrops atrox suggest that these are part of the normal microbiota of this snake species, which can cause diseases including stomatitis as a result of their opportunistic character when the animal is in a weakened state. It has been reported that the microorganisms commonly found as components of the microbiota in the digestive tract can act as etiological agents, but few researchers have defined these bacteria for Brazilian reptile species (DIAZ-FIGUEROA; MITCHELL, 2006).

In a study of microbiota of healthy Bothrops jararac, a Bastos et al. (2008) collected the samples directly from the colon. The authors succeeded in isolating several genera of the family Enterobacteriaceae, among which Salmonella, Citrobacter and Escherichia were the most frequent isolates. This indicates that these genera of bacteria are found in the intestinal microbiota of Bothrops jararaca, and these three genera were also isolated in our study on Bothrops atrox.

Like in Bothrops atrox, Jorge et al. (1990) isolated Escherichia coli, Proteus spp., Staphylococcus aureus, Salmonella Typhimurium and Citrobacter spp. in the microbiota from the fangs, fang sheaths and venom of Bothrops jararaca. The authors also described other microorganisms, such as group D Streptococci, Providencia rettgeri, Providencia spp., Morganella morganii, Clostridium spp. and Pseudomonas spp.

Careful prophylaxis and quarantine measures must be taken upon introducing free-living snakes in a stable breeding stock, because new animals can cause serious imbalances in the microbiota of captive specimens. The same care must be taken with the rodents that are fed to snakes, because they may carry pathogenic microorganisms that upset the balance of these microbiota (WILLIAMS, 2008).

In a recent study, Dehghani et al. (2016) analyzed oral cavity of venomous and non-venomous snakes and related that were similarly with the present study. The authors revealed the presence of Staphylococcus $(34.5$ 
$\%$ ) being the highest rate of infection and the lowest rate was represented for Pseudomonas (3.1\%), Proteus, Enterococcus, and Bacillus (each $6.2 \%$ ), Providencia (each $12.5 \%$ ), Salmonella (18.8\%) and Escherichia. The authors stand out that the significant presence of bacterial pathogens in oral cavity of snakes demonstrates the need not only anti-venom treatment but also, the diagnosis and treatment of infections.

Several studies have focused on the pharmacological activity of the venom of snakes of the genus Bothrops; hence, it is important to know which microbiota inhabit the oral cavity of these animals (FREITAS-DE-SOUSA et al., 2015; HAYASHI; CAMARGO, 2005; MOSCA, 2008; PÁRAMO et al., 1998; STIVAL, 2011). This type of information also provides subsidies to improve the treatment of stomatitis and health care of snakes from captivity to ensure a high quality venom.

\section{CONCLUSION}

All the analyzed samples showed bacterial growth, underscoring the high relevance of this type of research on commercially bred and wildlife snake species. The presence of Staphylococcus spp. only in snakes with stomatitis suggests that this microorganism is correlated with the occurrence of the pathology. While Proteus spp., Escherichia coli, Citrobacter spp., Serratia spp., Enterobacter spp., and Salmonella spp. occur in normal microbiota of Bothrops atrox.

\section{REFERENCES}

BASTOS, H. M. et al. Prevalence of enterobacteria in Bothrops jararaca in São Paulo State: microbiological survey and antimicrobial resistance. Acta Scientiarum - Biological sciences, Maringá, v. 30, n. 3, p. 321326, 2008.

BERNARDE, P. S. Serpentes peçonhentas e acidentes ofídicos no Brasil. São Paulo: Anolis Book, 2014. 224 p.

CASTRO, I. Estudo da toxicidade das peçonhas crotálicas e botrópicas, no acidente ofídico, com ênfase a toxicidade renal. 0 mundo da saúde, São Paulo, v. 30, n. 4, p. 644-653, 2006.

COSTA, C. C.; BÉRNILS, R. S. Répteis brasileiros: lista de espécies 2015. Herpetologia Brasileira, São Paulo, v. 4, n. 3, p. 75- 93, 2015.

DEHGHANI, R. et al. The identification of bacterial flora in oral cavity of snakes. Comparative Clinical Pathology, London, v. 25, n. 2, p. 279283, 2016.

DIAZ-FIGUEROA, O.; MITCHELL, M. A. Gastrointestinal anatomy and physiology. In: MADER, D. R. (Ed.). Reptile medicine and surgery. St. Louis: Saunders Elsevier, 2006. cap. 12, p. 145-162.

FONSECA, M. G. et al. Oral microbiota of Brazilian captive snakes. Journal of venomous animals and toxins including tropical diseases, Botucatu, v. 15, n. 1, p. 54-60, 2009.

FREITAS-DE-SOUSA, L. A. et al. Comparison of venoms from wild and long-term captive Bothrops atrox snakes and characterization of Batroxrhagin, the predominant class PIII metalloproteinase from the venom of this species. Biochimie, Paris, v. 118, n. 1, p. 60-70, 2015.
GIANNOTTI, K. C. et al. Viperid venom glands with defective venom production. Morphological study. Toxicon, Atlanta, v. 70, n. 1, p. 32-43, 2013.

HAYASHI, M. A. F.; CAMARGO, A. C. M. The Bradykinin-potentiating peptides from venom gland and brain of Bothrops jararaca contain highly site specific inhibitors of the somatic angiotensin-converting enzyme. Toxicon, Atlanta, v. 45, n. 8, p. 1163-1170, 2005.

JORGE, M. T. et al. Flora bacteriana da cavidade oral, presas e veneno de Bothrops jararaca: possível fonte de infecção no local da picada. Revista do Instituto de Medicina Tropical de São Paulo, São Paulo, v. 32, n. 1, p. 6-10, 1990.

JORGE, M. T. et al. Microbiological studies of abscesses complicating Bothrops snake bite in humans: a prospective study. Toxicon, Atlanta, v. 32, n. 8, p. 743-748, 1994.

KOLENISKOVAS, C.K.M.; GREGO, K.F.; ALBUQUERQUE, L.C.R. Ordem Squamata. Subordem Ophidia (Serpente). In: CUBAS, Z.; SILVA, J.C.R.; CATÃO-DIAS, J.L. Tratado de animais selvagens. São Paulo: Roca, 2006. cap. 8, p. 68-85.

MADER, D. R. Common bacterial disease and antibiotic therapy in reptiles. Compendium on continuing education for the practicing veterinarian, Yardley, v. 20, n. 1, p. 23-33, 1998.

MOSCA, R. C. Inibição do crescimento da microflora oral por venenos de serpentes. 2008. 85 f. Dissertação (Mestrado em Ciências) - Universidade de São Paulo, São Paulo, 2008.

OPLUSTIL, C. P. Procedimentos básicos em microbiologia clínica São Paulo: Sarvier, 2004. 340 p.

PÁRAMO, L. et al. Bactericidal activity of Lys49 and Asp49 myotoxic phospholipases A2 from Bothrops asper snake venom Synthetic Lys49 myotoxin II-(115-129) - peptide identifies its bactericidal region. European Journal of Biochemistry, Oxford, v. 253, n. 2, p. 452-461, 1998.

QUINN, L. M. et al. Drosophila Hfp negatively regulates dmyc and stgto inhibit cell proliferation. Development, Cambridge, v. 131, n. 6, p. 1411-1423, 2004

STIVAL, A. S. Avaliação da atividade não citotóxica do veneno da Bothrops moojeni em células mononucleares do sangue periférico humano. 2011. 48 f. Dissertação (Mestrado em Ciências Ambientais e Saúde) - Universidade Católica de Goiás, Goiânia, 2011.

WILKINSON, S. L. Guide to venomous reptiles in veterinary practice. Journal of Exotic Pet Medicine, v. 23, n. 4, p. 337-346, 2014.

WILLIAMS, D. L. Healthy herpetology: the role of the veterinarian in reptile prophylaxis. The Veterinary Journal, London, v. 175, n. 1, p. 16-17. 2008. 